\title{
PENGARUH PENGGUNAAN MEDIA SOSIAL TERHADAP PERILAKU MEMILIH PEMILIH PEMULA KOTA PADANG PADA PEMILIHAN KEPALA DAERAH KOTA PADANG TAHUN 2018
}

\author{
Nina Novita \\ Jurusan Ilmu Politik, Fakultas Ilmu Sosial dan Ilmu Politik, Universitas Andalas \\ Email: novitanina05@gmail.com
}

\begin{abstract}
Abstrak
Fenomena penggunaan media sosial yang meningkat dan sebagian besarnya adalah pemilih pemula yang aktif dalam bermedia sosial dapat memengaruhi pilihan pemilih pemula dalam pemilihan umum. Penelitian ini menggunakan teori uses and gratification dengan tiga variabel bebas, yaitu penggunaan media sosial Collaboractive Project (X1), penggunaan media sosial Blog and Microblogging dan Social Network (X2), dan penggunaan media sosial Content Comunities (X3) dengan variabel terikat yakni perilaku memilih pemilih pemula pada pemilihan Kepala Daerah Kota Padang tahun 2018. Penelitian ini menggunakan pendekatan kuantitatif desain survey dan tipe penelitian explanatory research. Temuan data di lapangan memperlihatkan bahwa penggunaan media sosial Collaboractive Project (X1), Blog and Microblogging dan Social (X2), dan Content Comunities (X3) tidak memengaruhi perilaku memilih pemilih pemula, dengan nilai Asymp. Sig > 0,05 X1; 0,658, X2; 0,150, dan X3; 0,164. Artinya, Ha ditolak dan $\mathrm{H} 0$ diterima.
\end{abstract}

Kata Kunci : Perilaku Memilih ; Pemilih Pemula ; Media Sosial

\begin{abstract}
Phenomenon of increasing use of social media and most of them are beginner voters as active social media users in social media can influence the choice of novice voters in general elections. This study uses the theory of uses and gratification with three independent variables, that are the use of social media collaborative projects (X1), the use of social media Blog and Microblogging and Social Networks (X2), and the use of media social Content Comunities (X3) with the dependent variable that is voting behavior of voters in the selection of mayor and deputy mayor of Padang City at 2018. This study uses a quantitative approach with survey research design, the type of research is explanatory research. Data findings in the field show that the use of collaborative project (X1), Blog and Microblogging and Social Network (X2), and Content Comunities (X3) does not affect voter voting behavior, with Asymp values. Sig> $0.05 \mathrm{X1}$; 0.658, X2; 0.150, and X3; 0.164. That is, Ha is rejected and HO is accepted.
\end{abstract}

Keywords: Voting Behavior ; Beginner Voters ; Social Media

\section{PENDAHULUAN}

Internet bukan hanya media hiburan tetapi telah menjadi sarana komunikasi dan informasi politik. Hasil survey yang dilakukan oleh Asosiasi Penyelenggara Jasa Internet Indonesia (APJII) pada tahun 2017 yang dilansir pada situs Kompas.com mengatakan bahwa bahwa pengguna internet di Indonesia Tahun 2017 menembus angka 143,27 juta dari total populasi penduduk. Walaupun penetrasi tertinggi masih didominasi oleh jawa, yakni $57,7 \%$ dari total penduduk Jawa. Sementara Sumatera menduduki tempat kedua dengan persentase pemakaian $19,05 \%$ dan penetrasi internetnya sebanyak $47,2 \%$. Dengan banyaknya jumlah pengguna millenial yang 
menggunakan media sosial tersebut sedikit banyaknya akan memberikan pengaruh kepada pengguna media sosial tersebut.

Fenomena media sosial juga bisa dilihat di Indonesia terkhusus sewaktu Pemilihan Walikota Padang tahun 2018. Peneliti melihat banyak faktor-faktor yang memengaruhi kemenangan Mahyeldi, diantaranya keterlibatan pemilih pemula yang menggunakan media sosial sebagai referensi pemilihan, kegiatan kampanye yang menggunakan media sosial, pembagian informasi tentang pasangan calon melalui blog ataupun akun-a3kun pendukung Mahyeldi di media sosial pada pemilihan walikota tahun 2018 ini. Pada fenomena Mahyeldi dapat kita lihat di media sosial melalui blogspot, Microblogging dan social networking diantaranya akun facebook dan instagram resmi Mahyeldi. Sebagai data, Mahyeldi mempunyai account official facebook Walikota Mahyeldi dengan total Likers page sekitar 15.671 orang. Sedangkan Emzalmi yang menjadi saingan Mahyeldi mempunyai account official dengan total Likers page sekitar 2.161 orang. Sementara itu, Mahyeldi juga mempunyai akun Instagram aktif, pengikut beliau sekitar 13.300 yang akan bertambah setiap harinya, sedangkan Emzalmi hanya memiliki 1486 pengikut.

Tabel 1

Jumlah Followers (kandidat)

\begin{tabular}{lll}
\hline \multirow{2}{*}{ Media Sosial } & Kandidat & $\begin{array}{l}\text { Jumlah } \\
\text { Pengikut }\end{array}$ \\
\hline Instagram & Mahyeldi & 13.400 \\
& Hendri Septa & 1966 \\
& Emzalmi & 1486 \\
& Desri Ayunda & 8136 \\
Facebook & Mahyeldi & 12.511 \\
& Hendri Septa & 740 \\
& Emzalmi & 142 \\
& Desri Ayunda & 372
\end{tabular}

\section{Sumber: Olahan Peneliti}

Jumlah followers diatas menunjukan bahwa diantara kandidat mengalami perbedaan, Mahyeldi adalah pemenang pada pemilihan Kepala Daerah Kota Padang tahun 2018 yang juga aktif dalam besosial media dan memiliki pengikut yang jauh lebih banyak dibanding lawan politiknya yaitu, Emzalmi. Media digunakan oleh sebagian masyarakat untuk membuat citra, membangun image agar bisa memengaruhi perilaku memilih mayarakat terutama pemilih pemula. Generasi millenial juga aktif dalam bersosial media dan mencari informasi-informasi dibidang politik untuk memenuhi kebutuhan mereka. Informasi yang diperoleh oleh generasi millenial dari media sosial tersebut akan memberikan efek atau dampak pada perilaku memilih mereka.

Sedangkan data yang diperoleh dari facebook ada tiga akun pendukung dengan nama akun Mahyeldi Hendri Septa, official account Mahyeldi Ansharullah yang sudah memiliki like ribuan dan ada satu grup dengan nama H. Mahyeldi Ansharullah, S.P 
Untuk Padang Kota Tercinta dengan jumlah anggota 14.290 anggota. Akun-akun tersebut berisikan informasi umum Mahyeldi, kegiatan-kegiatan Mahyeldi, serta aspirasi masyarakat dalam politik baik berupa pendapat, kritik ataupun saran untuk Mahyeldi yang akan membuat para pengguna media sosial tertarik dan menjadikan hal tersebut sebagai referensi dalam pemilihan.

Selain itu, jenis Content Communities yang berupa Youtube juga banyak terdapat video-video dari kegiatan-kegiatan, kampanye bahkan debat politik. Salah satunya debat politik yang disiarkan oleh Padang Tv juga diunggah ke Youtube dengan judul "Debat Terbuka Pertama Pemilihan Walikota Padang 2018 Segmen 1" dengan tanyangan 905x ditonton oleh pengguna media sosial dan masih banyak lagi kegiatan-kegiatan mahyeldi yang ada di Youtube yang diupload oleh akun yang berbeda. Dengan adanya unggahan ini pun sekaligus bisa berpengaruh pada perilaku memilih dari pemilih pemula. Peneliti melihat banyak faktor-faktor yang memengaruhi kemenangan Mahyeldi, salah satunya kegiatan kampanye yang menggunakan media sosial pada Pilkada tahun 2018 ini.

Pada pilwalkot 2018 ini dimenangkan oleh Mahyeldi dan Hendri Sapta dengan perolehan suara 212.526 suara $(62,92 \%)$. Sedangkan pasangan Emzalmi dan Desri Ayunda memperoleh suara sebanyak 125.238 suara (37,08\%). Kedua pasangan ini memiliki keistimewaan dan kelebihan masing-masing, karena kedua pasangan calon pernah menjabat sebagai Walikota dan Wakilwalikota Padang periode 2014-2018.

Berdasarkan latar belakang di atas, peneliti melihat adanya pengaruh penggunaan media sosial terhadap perilaku memilih pemilih pemula pada pemilihan Kepala Daerah Kota Padang tahun 2018. Hal tersebut dapat dilihat dari segi penggunaan media sosial baik berupa collaborative project (proyek kolaborasi), Blog and Microblogging serta social networking (jaringan sosial), dan Content Communities (Komunitas konten) oleh pemilih pemula sebagai referensi pemilihan pemimpin atau walikota yang memengaruhi perilaku memilih pemilih pemula. Alasan peneliti hanya mengambil fokus pada empat jenis media sosial ini karena merupakan aplikasi yang paling umum digunakan di Indonesia. Maka peneliti tertarik untuk meneliti bagaimana pengaruh kempat jemis penggunaan media sosial terhadap perilaku memilih pemilih pemula pada pemilihan Kepala Daerah Kota Padang tahun 2018.

\section{Media Sosial}

Media sosial bisa dikatakan sebagai sebuah media online, karena para penggunanya (user) melalui aplikasi berbasis internet dapat berbagi, berpartisipasi, dan menciptakan konten. Empat jenis media sosial yang digunakan dalam penelitian ini antara lain:

\section{Collaborative Project}

Merupakan suatu media sosial yang mengizinkan pengguna nya dapat membuat, mengubah, menambah atau pun menghapus konten tersebut dan dalam pembuatannya dapat diakses oleh khalayak secara global. Contoh; Wiki dan Bookmark social. 


\section{Blog dan Microblogging}

Blog dan Microblogging merupakan aplikasi yang dapat membantu penggunanya untuk mengekspresikan sesuatu, curhat ataupun mengkritik kebijakan pemerintah, contoh blogspot, facebook, instagram.

\section{Content Communities}

Content Communities merupakan jenis media sosial yang berfungsi untuk berbagi konten-konten media seperti video, gambar, atau suara. Contoh; Youtube, Flickr, dan Slideshare.

\section{Social Networking}

Social Networking merupakan situs paling umum untuk jenis ini adalah Facebook, Twitter, MySpace, Instagram, LinkedIn.

\section{Uses and Gratification}

Herbert Blumler dan Elihu Katz adalah orang pertama yang mengenalkan teori uses and gratifications. Teori ini dikenalkan pada tahun 1974 dalam bukunya The Uses of Mass Communication: Current Perspectives on Gratification Research. Teori ini banyak berkaitan dengan sikap dan perilaku para konsumen, bagaimana mereka menggunakan media untuk mencari informasi tentang apa yang mereka butuhkan. Teori uses and gratifications milik Blumler dan Katz ini mengatakan bahwa pengguna media memainkan peran aktif untuk memilih dan menggunakan media tersebut. Mereka percaya bahwa ada banyak alasan khalayak untuk memilih dan menggunakan media massa. Menurut pendapat teori ini, konsumen media mempunyai kebebasan untuk memutuskan bagaimana atau lewat media apa mereka menggunakan media dan bagaimana media itu akan berdampak pada dirinya.

Model ini tidak tertarik pada apa yang dilakukan media pada diri orang (what media do to people), tetapi ia tertarik pada apa yang dilakukan orang terhadap media (what people do to media).

Teori ini termasuk dalam tradisi sosio psikologis, dimana teori ini memandang individu sebagai, makhluk sosial. Maka teori ini digunakan dalam penelitian ini guna menemukan jawaban apa yang ada dibalik pengunaan khalayak terhadap media yang ada di era media baru, kebutuhan dan kepuasan yang terpenuhi dengan peggunaan terhadap media sosial.

\section{Perilaku Memilih}

Perilaku memilih merupakan kegiatan yang dilakukan seorang pemilih dalam menetapkan pilihannya dalam pemberian suara, baik dalam pemilihan umum, pemilihan presiden atau pemilihan kepala daerah (Pilkada).

Menurut Saiful Munjani, terdapat tiga pendekatan mengenai perilaku memilih, yaitu pendekatan sosiologis, psikologis dan pilihan rasional (rational choice).

1. Pendekatan Sosiologis

Pendekatan sosiologis pendekatan perilaku memilih ditentukan oleh karakteristik sosiologis para pemilih dalam sosial ekonomi, kelas sosial, sentiment keagamaan, dan kelompok etnik/kedaerahan/bahas, dan lain-lain. 


\section{Pendekatan Psikologis}

Pendekatan psikologis juga menjelaskan secara metodologis kecenderungankecenderungan yang ada dalam diri individu, terutama yang terkait dengan preferensi politiknya terhadap suatu partai. Menurut pendekatan ini, sosialisasi politik yang diterima seseorang sangat mempengaruhi pilihan politik mereka, terkhusus pada saat pertama kali menentukan pilihan politik.

\section{Pendekatan Pilihan Rasional}

Pendekatan ini muncul karena adanya ketidakpuasan terhadap pendekatan sosiologis dan psikologis. Menurut perspektif rasional pemilih ini, seseorang berperilaku rasional, yakni bagaimana mendapatkan hasil maksimal dengan ongkos minimal.

\section{Hubungan Penggunaan Media Sosial dengan Perilaku Memilih}

Pemilih yang berpartisipasi dalam pemilu bukan saja karena kondisinya lebih baik secara sosial-ekonomi, atau karena berada dalam jaringan sosial, akan tetapi ia tertarik dengan politik, punya perasaan dekat dengan partai tertentu. Inilah yang dimaksud dengan ikatan emosional pada satu partai tertentu. Orientasi kandidat dimana Pengetahuan individu (voter) terhadap keberadaan kandidat akan berdampak pada posisi kandidat tersebut dalam pilkada. Biasanya para voter lebih cenderung memberikan evaluasi terhadap kandidat berdasarkan latar belakang kandidat, track record kandidat, visi misi, dan popularitas kandidat.

Sedangkan Isu-isu kebijakan yang berkembang merupakan ketertarikan masyarakat terhadap isu-isu yang berkembang dan yang akan dikembangkan. Masyarakat melihat dari visi misi kandidat yang mencalonkan diri sebagai kepala daerah. Isu-isu politik yang berkembang tidak terlepas dari isu-isu yang sudah ada sebelumnya. Maka dari itu sangatlah perlu bagi masyarakat untuk melihat bagaimana isu-isu tersebut berkembang dan terlaksana dengan baik di lingkungannya.

Mempunyai informasi yang cukup tentang isu-isu yang berkembang untuk menentukan pilihan dan merasa suaranya serta percaya bahwa pilihannya dapat memperbaiki keadaan. Orang yang mempunyai informasi yang lebih banyak tentang masalah publik, akan cenderung lebih mampu menentukan sikap dan melakukan tindakan politik, seperti ikut dalam pemilihan umum. Sebaliknya jika orang yang kurang mempunyai informasi cenderung tidak akan bersika yang akan berdampak pada tindakan dan partisipasinya yang berkaitan dengan kepentingan publik. Oleh karena itu, informasi publik dapat membantu seseorang untuk ikut serta dalam pemilihan umum.

Oleh karena itu, penggunaan media sosial dengan mengakses informasi terkait informasi, visi misi dari kandidat, dan isu-isu yang berkembang di tengah masyarakat akan mempengaruhi perilaku memilih yang berupa tindakan politik mereka.

Selain itu, pengguna media sosial memiliki intensitas yang berbeda-beda dalam menggunakan media sosial. Dalam intensitas penggunaan media sosial akan terdapat kecendrungan dalam pembentukan identitas dimana mereka melihat, membaca isi atau 
konten dari media sosial yang berbeda. Pengetahuan politik dan teknologi media dari pengguna juga akan mempengaruhi motivasi seseorang untuk terlibat dalam isu politik.

Menariknya, teori pembelajaran sosial yang diutarakan oleh Bandura, bahwa sebagian besar dari pada tingkah laku manusia adalah diperoleh dalam diri, dan prinsip pembelajaran juga sudah cukup untuk menjelaskan bagaimana tingkah laku berkembang. Selain itu, teori ini juga menjelaskan apa yang ia lihat, diakses melalui media atau suatu proses yang disebut pembelajaran hasil pengamatan. Sehingga semakin tinggi paparan terhadap media dan konten berpengaruh dalam mempengaruhi pola pikir pengguna tersebut. Tinggi rendah paparan tersebut dipengaruhi seberapa sering seseorang menggunakan media tersebut. Serta ketertarikan terhadap stimulus yang dipaparkan dan diterima akan mempengaruhi perhatian dan berlanjut dengan pengolahan stimulus.

\section{Pemilih Pemula}

Pemilih pemula terdiri atas masyarakat yang telah memenuhi syarat untuk memilih, telah didaftarkan melalui pendataan yang dilakukan oleh petugas yang ditunjuk oleh penyelenggara pemilihan umum. Pemilih pemula dengan menggunakan pengertian dari Kemitraan Partnership for Governance Reforms yang menyebutkan bahwa pemilih pemula adalah pemilih yang mengikuti pemilu untuk pertama kali yang berusia muda sekitar 17-22 tahun maupun yang belum berumur 17 tahun tapi sudah pernah menikah.

\section{METODE PENELITIAN}

Metode penelitian yang digunakan dalam penelitian ini adalah kuantitatif, dengan desain survey, tindakan dalam pengumpulan data dengan mengedarkan kuesioner. Sedangkan tipe penelitian yang digunakan yaitu explanatory research. Lokasi penelitian adalah di Kota Padang. Penelitian ini dilakukan dengan cara pembagian kuesioner. Populasi dalam penelitian ini adalah seluruh pemilih pemula yang ada di Kota Padang sedang populasi sasaran dalam penelitian ini adalah pemilih pemula yang menggunakan hak pilih pada pemilihan Kepala Daerah Kota Padang tahun 2018 dan pemilih pemula yang menggunakan media sosial. Sampel dalam penelitian ini ditarik dengan menggunakan metode Multi Stage Sampling, yaitu stratified random sampling dan simple random sampling. Dalam penelitian ini, teknik atau cara-cara penarikan sampel dari setiap lapisan diambil sampel secara acak sederhana atau sistematis dengan perbandingan besarnya satuan elementer tiap-tiap stratum ialah 30:10:10. Untuk menentukan berapa banyak sampel yang diambil, digunakan rumus slovin, dari rumus slovin tersebut didapatilah sampel sebanyak 100 sampel. Unit analisis dalam penelitian ini adalah individu-individu yang berusia 17-22 tahun yang menjadi pemilih pemula yang menggunakan media sosial dan ikut memilih pada pemilihan Kepala Daerah Kota Padang tahun 2018. Analisis data yang digunakan Statistick Package For Social Sience 16.0 (SPSS 16.0). Uji hipotesis yang digunakan dalam penelitian ini adalah uji ChiSquare dan koefisien kontingency. 


\section{HASIL DAN PEMBAHASAN}

Penelitian ini melibatkan 100 responden dengan rentang umur 17-22 tahun yang merupakan pemilih pemula. dari 100 responden, ada sebanyak 58 orang responden atau dalam persen sebesar 58\% yang memilih pasangan Mahyeldi dan Hendri Sapta. Kemudian responden yang memilih Emzalmi dan Desri Ayunda ada sebanyak 7 orang responden atau dalam persen sebesar 7\%. Sedangkan 35 responden memilih merahasiakan pilihannya. Hal ini dapat disimpulkan bahwasanya mayoritas dari responden pemilih pemula lebih memilih Mahyeldi dan Hendri Sapta. Untuk hipotesis pertama, hasil penelitian nilai pearson chi-square kedua variabel sebesar 2,427 dengan degree of freedom (df) adalah 4. Diketahui bahwa $X^{2}$ tabel dengan df 4 adalah 9,487 pada tingkat kepercayaan $95 \%$ dan nilai asymp.Sig $>0,05$. Dengan demikian, hipotesis nol diterima dan hipotesis alternatif ditolak karena nilai $\mathrm{X}^{2}$ hitung lebih kecil dari nilai $\mathrm{X}^{2}$ tabel. Artinya tidak ada pengaruh antara variabel penggunaan media sosial Collaboractive Project (XI) terhadap perilaku memilih pemilih pemula terhadap Pilkada Kota Padang tahun 2018 (Y).

Ini berarti bahwa tidak adanya pengaruh antara penggunaan media sosial Collaboractive Project terhadap perilaku memilih pemilih pemula terhadap Pilkada Kota Padang tahun 2018. Hal tersebut menunjukan bahwa sebagian besar pemilih pemula Kota Padang tidak mengakses dan tidak menggunakan media sosial Collaboractive Project, sesuai dengan data yang ditemukan di lapangan. Selain itu pengguna intensitas menggunakan media sosial tidak menjadi faktor yang mendorong sebagian besar pemilih pemula dalam menentukan pilihan mereka.

Hipotesis kedua didapati nilai pearson chi-square $\left(\mathrm{X}^{2}\right)$ kedua variabel sebesar 6,745 dengan degree of freedom ( $\mathrm{df}$ ) adalah 4. Diketahui bahwa $\mathrm{X}^{2}$ tabel dengan df 4 adalah 9,4877 pada tingkat kepercayaan 95\% dan nilai asymp.Sig > 0,05. Dengan demikian, hipotesis nol ditolak dan hipotesis alternatif diterima karena nilai $\mathrm{X}^{2}$ hitung lebih kecil dari nilai $X^{2}$ tabel. Artinya tidak adanya pengaruh antara variabel penggunaan media sosial Blog and Microblogging dan Social Network (X2) terhadap perilaku memilih pemilih pemula terhadap Pilkada Kota Padang tahun 2018 (Y). Hasil tersebut dapat dibuktikan dengan analisis pada tabel 5.27 yang menjelaskan bahwa tidak ada hasil yang dominan yang menunjukan pemilih pemula yang menggunakan Blog and Microblogging dan Social Network merasakan simpatik atas informasi yang diterima yang juga tidak mempengaruhi psikologis mereka serta tidak memberikan pengaruh terhadap perilaku politik pemilih pemula tersebut. Selain itu, berdasarkan temuan data di lapangan diketahui bahwa sebagian besar pemilih pemula menggunakan jenis media sosial ini untuk medapatkan informasi kandidat. Akan tetapi, pada uji hipotesis didapti bahwa tidak terdapat hubungan antara penggunaan media sosial ini dengan perilaku memilih. Dapat disimpulkan bahwa, mengakses informasi belum tentu bisa memengaruhi perilaku memilih seseorang. 
Sedangkan untuk hipotesis ketiga didapati nilai pearson chi-square $\left(\mathrm{X}^{2}\right)$ kedua variabel sebesar 6,514 dengan degree of freedom (df) adalah 4. Diketahui bahwa $\mathrm{X}^{2}$ tabel dengan df 4 adalah 9,4877 pada tingkat kepercayaan 95\% dan nilai Asymp. Sig > 0,05 . Dengan demikian, hipotesis nol diterima dan hipotesis alternatif ditolak karena nilai $\mathrm{X}^{2}$ hitung lebih kecil dari nilai $\mathrm{X}^{2}$ tabel. Artinya tidak adanya hubungan antara variabel penggunaan media sosial Content Communities (X3) terhadap perilaku memilih pemilih pemula terhadap Pilkada Kota Padang tahun 2018 (Y).

Hasil tersebut dapat dibuktikan dengan temuan dilapangan yang menjelaskan bahwa sebagian kecil pemilih pemula merasa iya bahwa media sosial Content Communities memberikan pengaruh pada pilihan mereka pada Pilkada dengan persentase hanya $12 \%$. Sedangkan dengan yang merasa bahwa media sosial Content Communities tidak memberikan pengaruh pada pilihan mereka pada Pilkada dengan persentase sebesar 70\%. Dari data tersebut membuktikan bahwa tidak ada pengaruh antara penggunaan media sosial Content Communities memberikan pengaruh pada pilihan mereka pada Pilkada terhadap perilaku memilih pemilih pemula terhadap Pilkada Kota Padang tahun 2018.

Berdasarkan hasil analisis data dari uji hipotesis penelitian dari hubungan antara ketiga variabel independent (X) dengan satu variabel dependent (Y) penelitian, diperoleh hasil bahwa tidak ada variabel yang memiliki hubungan terhadap $\mathrm{Y}$. Dengakan kata lain, tidak adanya pengaruh penggunaan media sosial Collaboractive Project (X1)terhadap perilaku memilih pemilih pemula pada pemilihan Kepala Daerah Kota Padang tahun 2018 (Y). Tidak ada pengaruh penggunaan media sosial Blog and Microblogging dan Social Network terhadap perilaku memilih pemilih pemula pada pemilihan Kepala Daerah Kota Padang tahun 2018 (X2). Serta, tidak ada pengaruh penggunaan media sosial content communities terhadap perilaku memilih pemilih pemula pada pemilihan Kepala Daerah Kota Padang tahun 2018 (X3).

Sesuai dengan teori yang ada dalam penelitian, hasil penelitian menunjukan bahwa apa yang diakses pemilih pemula tidak memengaruhi pola pikir dan pilihan mereka dalam memilih berdasrkan pedoman atau pengetahuan yang diakses. Hasil penelitian menunjukan bahwa mayoritas pemilih pemula yang menggunakan media sosial untuk mencari informasi, latar belakang, visi misi, track record, dan isu-isu yang berkembang pada kandidat tidak berpengaruh pada pilihan mereka, karena itu belum tentu memengaruhi psikologis dengan perasaan atau emosional yang dimiliki oeh pemilih pemula tersebut. Jadi, dari 3 jenis media sosial di atas dapat disimpulkan bahwa sebagian besar pemilih pemula mengakses informasi kandidat melalui jenis media sosial blog and migroblogging dan social network, akan tetap itu tidak memngaruhi perilaku memilih mereka.

\section{KESIMPULAN}

Berdasarkan pembahasan dari bab terdahulu diketahui bahwa tiga variabel, yaitu penggunaan media sosial Collaboractive Project (Wikipedia), Blog and Microblogging 
dan Social Network (Blogspot, facebook, twitter, instagram), dan Content Comunities (Youtube) tidak memengaruhi perilaku memilih pemilih pemula dalam pemilihan Kepala Daerah Kota Padang tahun 2018.

Berdasarkan analisis data nilai chi-square vaiabel penggunaan media sosial Collaboractive Project (Wikipedia) dengan variabel perilaku memilih pemilih pemula dalam pemilihan Kepala Daerah Kota Padang tahun 2018 sebesar 2,427 dengan degree of freedom (4). Sedangkan variabel penggunaan media sosial Blog and Microblogging dan Social Network (Blogspot, facebook, twitter, instagram) dengan variabel perilaku memilih pemilih pemula dalam pemilihan Kepala Daerah Kota Padang tahun 2018 sebesar 6,745 dengan degree of freedom (df) 4. Sedangkan variabel penggunaan media sosial content communities dengan variabel perilaku memilih pemilih pemula dalam pemilihan Kepala Daerah Kota Padang tahun 2018 sebesar 6,514 dengan degree of freedom (4). Diketahui chi-square tabel dengan df 4 adalah 9,4877 pada tingkat kepercayaan 95\%. Dengan demikian, hipotesis satu (1) didapati bahwa hipotesis nol diterima karena nilai $\mathrm{X}^{2}$ hitung lebih kecil dari nilai $\mathrm{X}^{2}$ tabel. Artinya tidak adanya pengaruh penggunaan media sosial Collaboractive Project (Wikipedia) dengan perilaku memilih pemilih pemula dalam pemilihan Kepala Daerah Kota Padang tahun 2018.

Sedangkan hipotesis kedua (2) didapati bahwa hipotesis nol diterima karena nilai X2 hitung lebih kecil dari nilai X2 tabel. Artinya tidak adanya pengaruh penggunaan media sosial Blog and Microblogging dan Social Network (Blogspot, facebook, twitter, instagram) dengan perilaku memilih pemilih pemula dalam pemilihan Kepala Daerah Kota Padang tahun 2018. Untuk hipotesis ketiga (3) didapati bahwa hipotesis nol diterima karena karena nilai $\mathrm{X}^{2}$ hitung lebih kecil dari nilai $\mathrm{X}^{2}$ tabel. Artinya tidak adanya pengaruh penggunaan media sosial penggunaan media sosial content communities dengan perilaku memilih pemilih pemula dalam pemilihan Kepala Daerah Kota Padang tahun 2018.

\section{DAFTAR PUSTAKA}

\section{Buku}

Asrinaldi. 2012. Politik Masyarakat Miskin Kota. Yogyakarta: Gava Media

Alam, Lukis. 2009. Influinsasi Media Internet Terhadap Proses Pemilu Di Indonesia. Jurnal Seminar Nasional Informatika. Vol.1. No. 6

Cangara, Hafied. 2011. Komunikasi Politik Konsep, Teori dan Strategi. Jakarta:PT Rajagrafindo persada.

Gromarck, Jonathan dan Michael Shliesmann. The effect of Politicians Social Media Activityon Voting Behavior (Twitteron Usage During the 2010 U. S House of Representative Election). Thesis Departement of Economics Stockholm School Of Economics. U.S. 201. 
Kaplan, Andreas M., and Michael Haenlein.2010. "Users of the world, unite! The challenges and opportunities of Social Media. Business horizons. Vol 53 No 1.2010. 59-68

Mujani, Saiful et.al. 2012. KUASA RAKYAT. Jakarta: Noura Books

Peldi, Elza dan Yulia Purnawati. 2003. Panduan Pelatihan Pendidikn Pemilu 2004. Jakarta: Kemitraan Partnership.

Rakhmat, Jalaluddin. 2005. Metode Penelitian Komunikasi. Bandung: PT. Remaja Rosdakarya.

Rasul, Najmuddin M., dkk.2015. "Media Usage, Citizensip Norms, and Political Participant of Transition to Democracy In Indonesia", Jurnal Komunikasi Malaysia Journal of Communication. Atens Institute for Education and Research.

Sugiyono.2010. Metode Penelitian Kuantitatif Kualitatif dan R\&D. Bandung: ALFABETA

\section{Berita}

Padang TV. 2018. Debat Terbuka Pertama Pemilihan Kepala DaerahPadang 2018

Segmen 2. youtube . (http://youtu.be/sl-AtBJraDw). Diakses pada tanggal 20 Februari 2019

Sepania, Rizky Chandra. 2018. Ini Daerah di Indonesia yang Paling Rajin Internetan. 2018. Kompas.com. diakses pada tanggal 28 Januari 2018 (http://tekno.kompas.com)

www.facebook.com (https://www.facebook.com/Emzalmi1) Di Akses 02 Oktober 2018 www.instagram.com (https://www.instagram.com/mahyeldisp /)Di Akses Tanggal 8 Oktober 2018

Youtube. 2018. Debat Terbuka Pertama Pemilihan Kepala DaerahPadang 2018 Segmen 1. Padang TV . (http://youtu.be/sl-AtBJraDw). Diakses pada tanggal 20 Februari 2019 http:// Infopemilu.kpu.go.id 